\title{
Honey as Natural Sweetener in Lemon Ready-to-Serve Drink
}

\author{
S. Sharma ${ }^{1 *}$, D. Vaidya ${ }^{2}$ and N. Rana ${ }^{3}$ \\ ${ }^{1}$ Institute of Food Science and Technology, Majrigrant, Dehradun, VCSG Uttarakhand University of Horticulture and \\ Forestry, Uttarakhand (248 041), India \\ ${ }^{2}$ Dept. of Food Science and Technology, ${ }^{3}$ Dept. of Basic Sciences, Dr. Y. S. Parmar University of Horticulture and \\ Forestry, Nauni, Solan, Himachal Pradesh (173 230), India
}

\section{Article History}

Manuscript No. AR1389

Received in $18^{\text {th }}$ June, 2015

Received in revised form $28^{\text {th }}$ February, 2016

Accepted in final form $15^{\text {th }}$ March, 2016

\section{Correspondence to}

"E-mail: surbhisml@gmail.com

\section{Keywords}

Honey, multifloral, lemon, RTS, antioxidant activity, table sugar

\begin{abstract}
The present study was conducted to prepare an acceptable ready-to-serve drink by ameliorating honey in lemon juice. Honey a natural sweetener highly nutritious; antioxidant rich and wholesome safe food can be used as substitute for table sugar especially in fruit beverages. Lemon fruit juice a rich source of vitamin C, minerals, carotene and distinct flavor, was utilized along with honey for the preparation of ready-to-serve lemon beverage and was analysed for different physico-chemical characteristics both in raw and processed forms. Honey contains significantly less nonreducing sugars $(6.78 \%)$ as compared to table sugar $(89.41 \%)$. The quality of honey can be judged by two indicative parameters i.e. hyrdoxymethyl furfural (HMF) and diastase activity. The hydroxymethylfurfural content recorded in mixed flora honey was $19.36 \mathrm{ppm}$ which was well below the maximum acceptable limits. The quality characteristics of the ready-to-serve drink were evaluated for a period of six months under different storage conditions and showed that honey lemon RTS had significantly higher ascorbic acid content (26.66 mg $\left.100 \mathrm{~g}^{-1}\right)$ and antioxidant activity (27\%) than the sugar lemon RTS (ascorbic acid $23.34 \mathrm{mg} 100 \mathrm{~g}^{-1}$, antioxidant activity $22 \%$ ) at fresh stage. Honey lemon RTS awarded with better sensory scores for colour, flavor, taste and overall acceptability over sugar lemon RTS even after storage of six months with minimal changes in its quality characteristics under refrigerated storage and no microbial growth. The natural ready-to-serve beverage made from completely natural ingredients is storage stable and can be commercialized as instant energy drink.
\end{abstract}

\section{Introduction}

Honey is a sweet, viscous liquid prepared by bees from nectar collected from plant nectaries and stored by them for food (White, 1975). It has been used since ancient times and has gained appreciation as the only concentrated form of sweetener available worldwide (FAO, 1996). Honey is a natural sweetener and its sweetness is due to fructose and glucose and has approximately the same sweetness as that of granulated sugar (www.honey.com). It is a natural biological product that comprises of simple sugars mainly glucose and fructose (70-80\%), water (10-20\%), and other minor constituents such as organic acids, mineral salts, vitamins, proteins, phenolic compounds and free amino acids (Ouchemoukh et al., 2007). Honey also serves as a source of natural antioxidants, which are effective in reducing the risk of heart disease, cancer, immunesystem decline, cataract and different inflammatory processes (National Honey Board, 2003). Honey can also prevent deteriorative oxidation reactions in foods such as enzymatic browning of fruit and vegetables (Chen et al., 2000), lipid oxidation in meat (Gheldof and Engeseth, 2002; McKibben and Engeseth, 2002; Nagai et al., 2006) and inhibit the growth of food borne pathogens and food spoilage organisms (Mundo et al., 2004; Taormina et al., 2001). It is liked by consumers for its neutraceutical value, characteristic flavour, sweetness, and texture (Subramanian et al., 2007). The processed honey can also be utilized as a replacement of table sugar, as it is a natural sweetening agent having nutritional quality, as table sugar (primarily sucrose) has been a part of the daily diet for hundreds of years, but research is now suggesting that more sugar intake can be detrimental to our health. In particular, excessive consumption of table sugars with high glycemic index (GI) has been shown to cause overeating and weight gain. So, this natural sweetening agent (honey) can be mixed with fruit juices or pulps for the preparation of some ready- 
to-serve beverages.

Citrus fruits have attractive bright colour, appealing taste and flavor. Lemon fruit part of the citrus family contains fair amount of carbohydrates and minerals including calcium besides the presence of $\mathrm{Cr}, \mathrm{Zn}, \mathrm{Fe}, \mathrm{Mn}, \mathrm{Cu}$ and $\mathrm{Mg}$ (Gopalan et al., 2002) and is also effective in cholesterol reduction (Bhuiyan et al., 2012). Juice of lemon fruit is best known remedy for the treatment of scurvy and useful for rheumatism, dysentery, diarrhea, cough, cold and fever as it is a rich source of ascorbic acid. There is a great potential to use this fruit in value added products such as diet drinks. These types of citrus drinks are probably the most recognized and globally accepted fruit beverages (Nchez-moreno et al., 2003). However, sucrose is being used as the sweetening agents in these drinks which can increase the intake of empty calories.

Alternative sweeteners can avoid problems with dental decay and other health risks associated with the excessive consumption of caloric sweeteners, such as sucrose (Cardello and Damasio, 1997). In India, use of artificial and natural sweeteners is limited but being economical, these are helpful in controlling obesity and other potential diseases. A variety of artificial sweeteners are available in the market like, aspartame, cyclamate, sucralose, saccharin, and acesulfame-K (potassium salt of acesulfame) etc. These are the non-nutritive sweeteners which are not metabolized by the body and do not contribute any energy or calories to the diet but their use is restricted because of certain health hazards (American Dietary Association, 2004). However, nutritive natural sweeteners like honey can replace artificial sweeteners in the energy diet drinks with health safety. The home made lemon honey beverage has a short storage life and needs to be freshly prepared every time for consumption, keeping in view the health benefits of this beverage, the present study was conducted to make product more acceptable and as an instant energy drink with natural contents in ready-to-use form.

\section{Materials and Methods}

The study was conducted in the year 2011-2013 in the Department of Food Science and Technology, Dr. Y.S. Parmar University of Horticulture and Forestry, Solan 173230 , Himachal Pradesh. The lemon RTS beverage was prepared according to FPO specifications (1955). Fresh squeezed lemon juice was ameliorated with different sweetening agents (honey and table sugar) to prepare lemon RTS. The prepared lemon RTS beverage were packed in $200 \mathrm{ml}$ sterilized glass bottles, corked and processed at standardized processing temperature for honey $\left(77^{\circ} \mathrm{C}\right)$ for $30 \mathrm{~min}$. The final product was stored for six months at two different temperatures viz., room temperature $\left(13-27^{\circ} \mathrm{C}\right.$ and $\left.44.5-81.0 \% \mathrm{RH}\right)$ and refrigerated temperature (4-7 ${ }^{\circ} \mathrm{C}$ and $\left.73 \% \mathrm{RH}\right)$. Total soluble solids (TSS) was measured using Erma hand Refractometer and expressed as degree Brix $\left({ }^{\circ} \mathrm{B}\right)$, AOAC (2000). The moisture content was determined by oven drying method as given by Ranganna, 2007. The titratable acidity was estimated by the standard method (AOAC, 2000). The sugars were estimated by the method given by Lane and Enon, 1923. HMF was determined by Luh, Leonard and Marsh's (1948) method as reported by Ranganna, 2007. Nonenzymatic browning was recorded by measuring the optical density of alcoholic extracts of centrifuged samples (2000 $\mathrm{rpm}$ ) at $440 \mathrm{~nm}$ by spectrophotometer (Model Shimadzu, Japan) using 60\% ethanol as blank (Ranganna, 2007). Total acidity (free acidity+lactone) was determined by titrimetric method prescribed by AOAC, 2000. Fructose-glucose ratio was determined according to the method given by GOI, 2005. Quantitative analysis of antioxidant compounds was also evaluated like ascorbic acid content was determined as per standard AOAC method using 2, 6-dichlorophenol indophenol dye, the amounts of total phenolics in the beverages were determined with the Folin-Ciocalteu reagent according to the method of Bray and Thorpe (1954) using catechol as a standard.

Antioxidant activity (Free radical scavenging activity) was measured as per the method of Brand-Williams et al. (1995). DPPH (2, 2-diphenyl-1-picrylhydrazyl) was used as a source of free radical. A quantity of $3.9 \mathrm{ml}$ of $6 \times 10-^{5} \mathrm{~mol} \mathrm{~L}^{-1} \mathrm{DPPH}$ in methanol was put into a cuvette with $0.1 \mathrm{ml}$ of sample extract and the absorbance was measured at $515 \mathrm{~nm}$ after 30 min. Methanol was used as blank. Antioxidant activity was calculated using following equation:

Where, Antioxidant activity $(\%)=\frac{\mathrm{Ab}(\mathrm{B})-\mathrm{Ab}(\mathrm{S})}{\mathrm{Ab}(\mathrm{B})} \times 100$

$\mathrm{Ab}(\mathrm{B})=$ Absorbance of blank, $\mathrm{Ab}(\mathrm{S})=$ Absorbance of sample

Sensory evaluation of lemon RTS were conducted before and during storage on the basis of colour/appearance, flavour/ aroma, body, taste and overall acceptability on a 9 point hedonic scale according to the method of Amerine et al., 1965. Results were expressed as mean values \pm standard deviations. Each analysis assay was done three times from the same sample to determine reproducibility.

\section{Results and Discussion}

Table 1 shows the physico-chemical analysis of mixed floral honey, table sugar and lemon fruit. The honey used for the preparation of honey lemon RTS had total soluble solids of $77^{\circ} \mathrm{B}$, which was less than the observations of Kaushik et al., 1993 and the table sugar had a TSS of $94 \%$. The total acids and $\mathrm{pH}$ of mixed floral honey was 4.37 m.e. $100 \mathrm{~g}^{-1}$ and 3.39 respectively, which were well within the range as recorded by Singh et al. (1988) and Kaushik et al. (1993). Honey contains significantly less non-reducing sugars $(6.78 \%)$ where as table sugar contains high content of non-reducing sugars $(89.41 \%)$. Mishra (1995) recorded the total sugars and non-reducing sugars of mixed floral honey; these were near to the values 


\begin{tabular}{lccc}
\hline \multicolumn{4}{l}{$\begin{array}{l}\text { Table 1: Physico-chemical characteristics of sweetening agents } \\
\text { (mixed flora honey, table sugar and lemon fruit) }\end{array}$} \\
\hline Parameters & $\begin{array}{c}\text { Mixed flo- } \\
\text { ra honey }\end{array}$ & $\begin{array}{c}\text { Table } \\
\text { sugar }^{*}\end{array}$ & $\begin{array}{c}\text { Lemon } \\
\text { fruit }^{*}\end{array}$ \\
\hline Total soluble solids, ${ }^{\circ} \mathrm{B}$ & $77.0 \pm 0.019$ & $94.0 \pm 1.15$ & $7.85 \pm 0.15$ \\
Free acid, m.eq. 100 g ${ }^{-1}$ & $3.52 \pm 0.07$ & - & - \\
Lactone, m.eq. 100 g- & $0.85 \pm 0.04$ & - & - \\
Total acid, m.eq. 100 g g $^{-1}$ & $4.37 \pm 1.21$ & - & - \\
Titratable acidity, \% & - & - & $5.02 \pm 0.2$ \\
pH & $3.39 \pm 0.56$ & $6.08 \pm 0.83$ & $2.40 \pm 0.03$ \\
Reducing sugars, \% & $65.44 \pm 1.42$ & $4.48 \pm 0.76$ & $1.59 \pm 0.01$ \\
Non-reducing sugars, & $6.78 \pm 0.36$ & $89.41 \pm 1.24$ & $0.4 \pm 0.011$ \\
$\%$ & & & \\
Total sugars, \% & $72.22 \pm 1.03$ & $93.79 \pm 1.82$ & $2.08 \pm 0.1$ \\
Moisture, \% & $16.79 \pm 1.02$ & $3.40 \pm 0.15$ & $89.00 \pm 1.5$ \\
Total solids, \% & $83.21 \pm 1.32$ & $96.60 \pm 1.13$ & $11.00 \pm 0.05$ \\
Ash, \% & $0.12 \pm 0.01$ & $0.07 \pm 0.02$ & $0.3 \pm 0.001$ \\
Sulphur dioxide, ppm & - & $19.7 \pm 1.01$ & - \\
Hydroxymethylfurfu- & $19.36 \pm 1.27$ & - & - \\
ral, ppm & & & \\
Fructose, \% & $39.19 \pm 0.93$ & - & $0.6 \pm 0.001$ \\
Glucose, \% & $30.25 \pm 0.07$ & - & $0.8 \pm 0.005$ \\
Fructose: glucose ratio & $1.16 \pm 0.02$ & - & $0.75 \pm 0.01$ \\
\hline
\end{tabular}

recorded in the investigation. The indicative parameter for freshness of honey is determined by hydroxymethylfurfural which was observed to be $19.36 \mathrm{ppm}$ and was higher than the observations of Bulut and Kilic, 2009 but well below the maximum acceptable limit. The fructose and glucose content in mixed floral honey recorded was $39.19 \%$ and $30.25 \%$ respectively and was in the same range as observed by Poncini and Winner, 1987; Singh, 1994; Singh et al. (1988).

The lemon juice utilized for the preparation of lemon RTS was analysed for different physico-chemical characteristics. The total soluble solids were found to be $7.85^{\circ} \mathrm{B}$ with the acidity

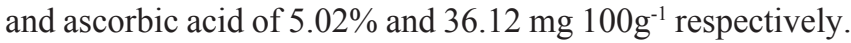
However, the lemon fruit has a low amount of glucose $(0.80 \%)$ and fructose $(0.6 \%)$.

The total soluble solids of honey and sugar based lemon readyto-serve (RTS) was $15{ }^{\circ} \mathrm{B}$ and acidity of $0.3 \%$ which was in accordance with the FSSAI standards (Table 2). The ascorbic acid content was significantly higher in honey based lemon

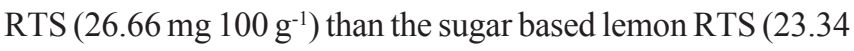
$\mathrm{mg} 100 \mathrm{~g}^{-1}$ ), as reported by Bogdanov (2008) as honey contains ascorbic acid and was also observed by Lakhanpal (2010) in honey based fruit nectars. The phenol content of honey based lemon RTS and sugar based RTS was 10.45 and $4.46 \mathrm{mg}$
$100 \mathrm{~g}^{-1}$ respectively (Figure 1) which together with ascorbic acid contributes to the antioxidant activity. The higher phenolic content of honey based RTS was due to the presence of phenols in honey (Saxena et al., 2010), which might be due to the multi floral nectars collected by the honeybees. However, the antioxidant activity was $27 \%$ in honey based RTS and $22 \%$ in sugar based RTS (Figure 2) as the honey has high antioxidant activity. The non-reducing sugars mainly sucrose was lower in honey based lemon RTS which leads to lower Glycemic index in honey (Saxena et al., 2010) (Figure 3) and can be considered as a drink for diabetic people. The non-enzymatic browning was higher in honey lemon RTS which might be due to the development of HMF content of honey. The sensory scores reveal that the honey lemon RTS had higher scores for colour, flavor, taste and overall acceptability at fresh stage (Figure 4) as compared to the stored samples (Figure 5).

Table 2: Quality characteristics of lemon Ready-to-serve beverage at fresh stage

\begin{tabular}{lccc}
\hline Parameters & $\begin{array}{c}\text { Honey } \\
\text { lemon RTS }\end{array}$ & $\begin{array}{c}\text { Sugar } \\
\text { lemon RTS }\end{array}$ & $\begin{array}{c}\mathrm{CD} \\
(p=0.05)\end{array}$ \\
\hline $\mathrm{TSS},{ }^{\circ} \mathrm{B}$ & 15.17 & 15.17 & 0.65 \\
Acidity, \% & 0.43 & 0.41 & 0.05 \\
Ascorbic acid, mg & 26.66 & 23.34 & 0.44 \\
$100 \mathrm{~g}^{-1}$ & & & \\
Reducing sugars, \% & 13.22 & 9.52 & 0.10 \\
$\begin{array}{l}\text { Total sugars, \% } \\
\text { Non enzymatic }\end{array}$ & 14.73 & 14.79 & 0.09 \\
$\begin{array}{l}\text { browning } \\
\text { TPC, log cfu g- }\end{array}$ & 0.19 & 0.07 & 0.01 \\
\hline
\end{tabular}

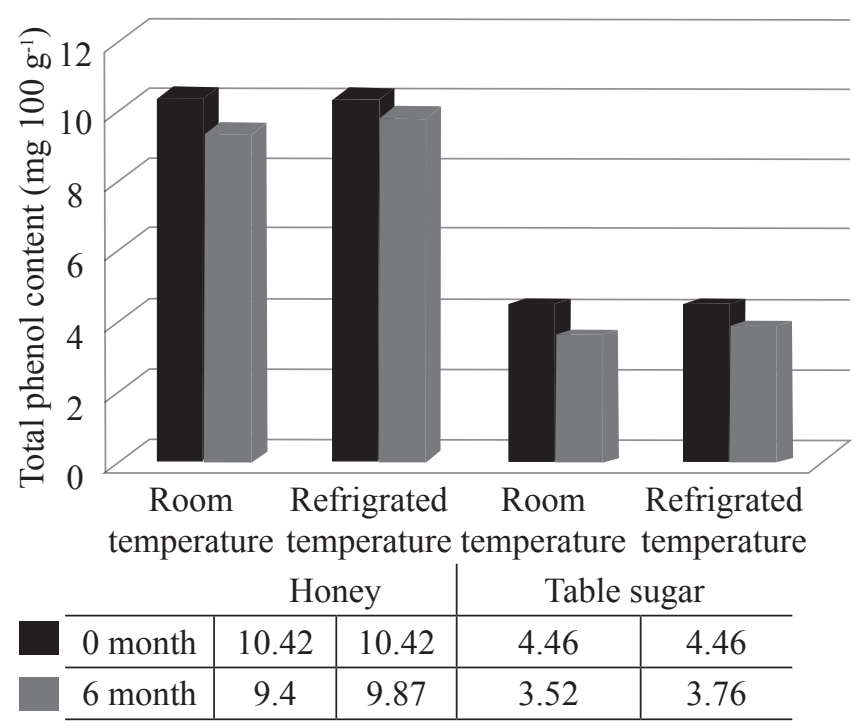

Figure 1: Effect of storage on total phenol $\left(\mathrm{mg}^{\left.100 \mathrm{~g}^{-1}\right)}\right.$ of honey and sugar based lemon beverage 


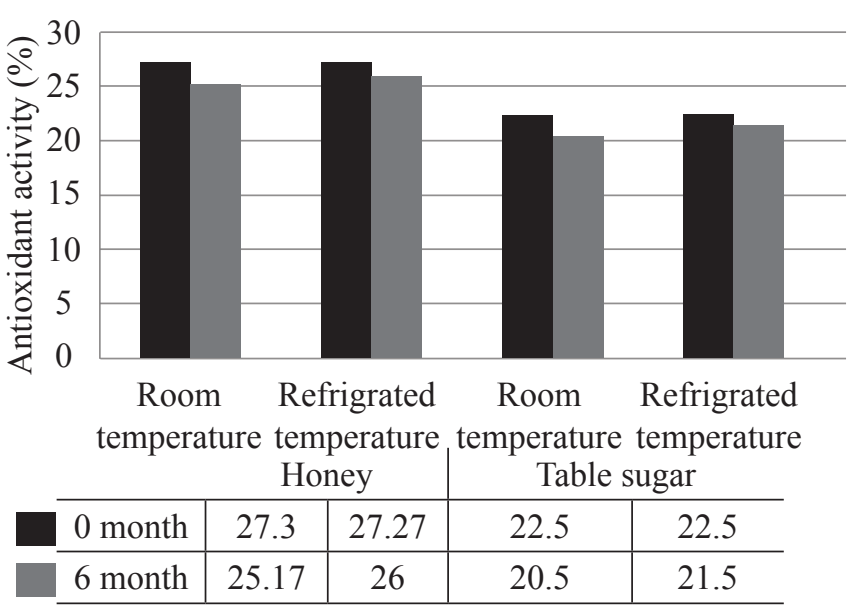

Figure 2: Effect of storage on Antioxidant activity (\%) of honey and sugar based lemon beverage

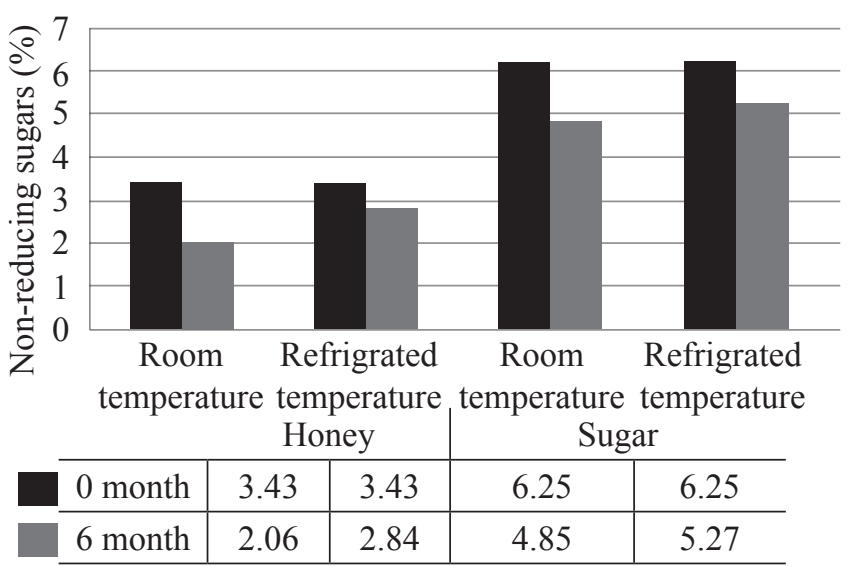

Figure 3: Effect of storage on non-reducing sugars (\%) of honey and sugar based lemon beverage

The sugar and honey based RTS were stored for a period of six months, under two different storage conditions i.e. refrigerated and room temperature. It was observed that samples kept under

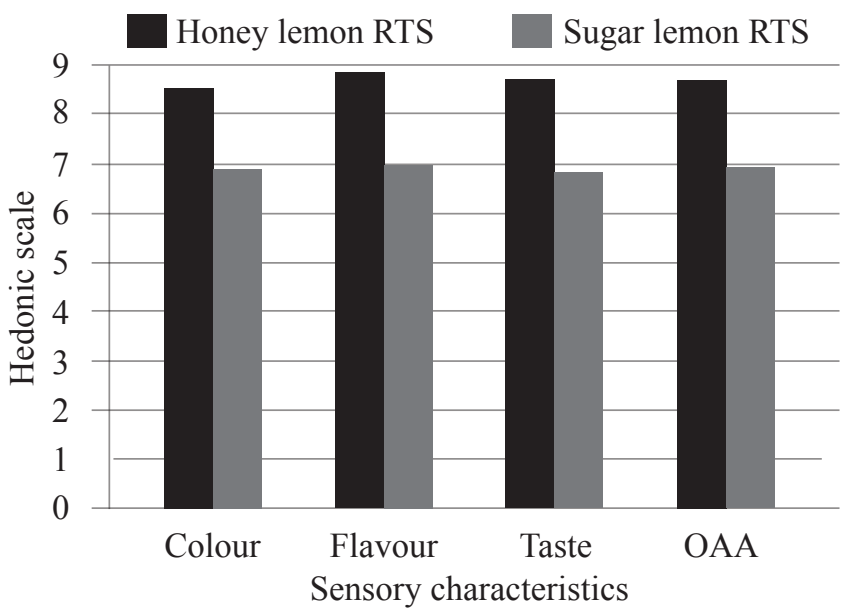

Figure 4: Effect of sweetening agents on the sensory quality of honey and sugar lemon RTS refrigerated conditions had non-significant changes in the physico- chemical (Table 3 and 4) and sensory characteristics (Figure 4 and 5), however under room temperature also this honey based health drink could be successfully stored for a period of six months with no microbial growth.

The sensory scores reveal that the honey lemon RTS had higher scores for colour, flavor, taste and overall acceptability, similar to the results of Lakhanpal, 2010 for honey based fruit nectars. The sugar and honey based lemon RTS were successfully

Honey lemon RTS (Refrigrated storage) Sugar lemon RTS (Refrigrated storage) Honey lemon RTS (Room storage) Honey lemon RTS (Room storage)

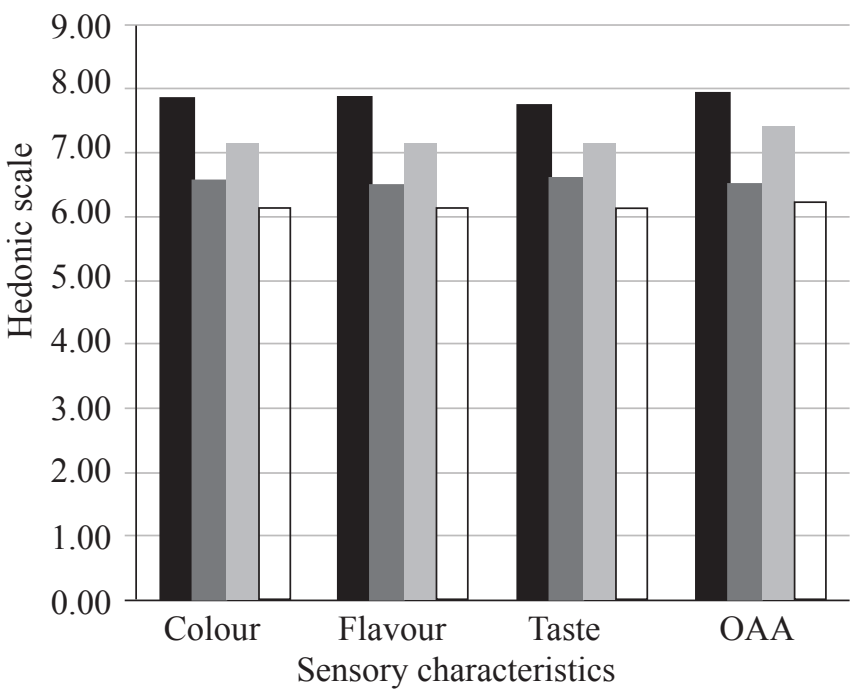

Figure 5: Effect of sweetening agents on the sensory quality of honey and sugar lemon RTS after six months of storage

Table 3: Effect of storage on the quality parameters of honey lemon ready-to-serve beverage

\begin{tabular}{lcccc}
\hline Parameters & $\begin{array}{c}\text { Honey } \\
\text { lemon } \\
\text { RTS }\end{array}$ & \multicolumn{2}{c}{$\begin{array}{c}\text { After six } \\
\text { months storage }\end{array}$} & \begin{tabular}{c} 
CD \\
\cline { 3 - 4 }
\end{tabular} \\
\cline { 3 - 4 } & $\begin{array}{c}\text { Room }=0.05) \\
\text { temp }\end{array}$ & $\begin{array}{c}\text { Ref. } \\
\text { temp }\end{array}$ & \\
\hline TSS, ${ }^{\circ} \mathrm{B}$ & 15.17 & 14.00 & 14.60 & 0.04 \\
Acidity, \% & 0.43 & 0.39 & 0.41 & 0.001 \\
Ascorbic acid, mg & 26.66 & 17.34 & 20.23 & 0.09 \\
100 g-1 & & & & \\
Reducing sugars, \% & 13.22 & 10.04 & 11.46 & 0.71 \\
Total sugars, \% & 14.73 & 12.81 & 13.34 & 0.01 \\
Non enzymatic & 0.19 & 0.310 & 0.215 & 0.002 \\
browning & & & & \\
TPC, log cfu g-1 & $\mathrm{NF}^{*}$ & $\mathrm{NF}$ & $\mathrm{NF}$ & \\
\hline
\end{tabular}

${ }^{*} \mathrm{NF}=$ Not found 


\begin{tabular}{|c|c|c|c|c|}
\hline \multirow[t]{2}{*}{ Parameters } & \multirow{2}{*}{$\begin{array}{c}\text { Sugar } \\
\text { lemon } \\
\text { RTS }\end{array}$} & \multicolumn{2}{|c|}{$\begin{array}{c}\text { After six } \\
\text { months storage }\end{array}$} & \multirow[t]{2}{*}{$\begin{array}{c}\mathrm{CD} \\
(p=0.05)\end{array}$} \\
\hline & & $\begin{array}{l}\text { Room } \\
\text { temp }\end{array}$ & $\begin{array}{l}\text { Ref. } \\
\text { temp }\end{array}$ & \\
\hline TSS, OB & 15.17 & 14.78 & 15.01 & 0.11 \\
\hline Acidity, \% & 0.43 & 0.37 & 0.38 & 0.0001 \\
\hline $\begin{array}{l}\text { Ascorbic acid, mg } \\
100 \mathrm{~g}^{-1}\end{array}$ & 23.34 & 18.88 & 20.97 & 0.06 \\
\hline Reducing sugars, $\%$ & 9.52 & 7.41 & 8.08 & 0.07 \\
\hline Total sugars, $\%$ & 14.79 & 12.19 & 12.92 & 0.13 \\
\hline $\begin{array}{l}\text { Non enzymatic } \\
\text { browning }\end{array}$ & 0.070 & 0.130 & 0.103 & 0.002 \\
\hline TPC, $\log$ cfu g ${ }^{-1}$ & $\mathrm{NF}^{*}$ & NF & NF & \\
\hline
\end{tabular}

stored for a period of six months, under two different storage conditions i.e. refrigerated and room temperature.

\section{Conclusion}

On the basis of physico-chemical, shelf-life and sensory analysis of honey lemon RTS, it can be an excellent substitute for the other sugar based or carbonated drinks available in the market as it is made from completely natural ingredients with no artificial sweetener, flavor or colour. As the consumers are more concerned about their health, higher amount of ascorbic acid and phenols contribute for better antioxidant activity than the traditional ready-to-serve beverages. Thus, it can be concluded that this drink can be commercialized in ready-toserve form as it can serve as a source of instant energy with low glycemic index.

\section{Acknowledgement}

I am thankful to the Department of Science and Technology, Government of India and All India Coordinated Research Project (AICRP) on PHT, Department of Food Science and Technology, Dr. Y.S. Parmar University of Horticulture and Forestry, Solan-173230, Himachal Pradesh, for providing financial assistance for the research.

\section{References}

American, Dietary, Association., 2004. Use of nutritive and nonnutritive sweeteners. J Am Diet Assoc 104, 255-275.

Amerine, M.A., Pangborn, R.M., Roessler, E.B., 1965. Principles of sensory evaluation of food. Academic Press, Inc., New York.

AOAC., 2000. Official Methods of Analysis. Association of Official Analytical Chemists, Washington, DC, USA.
Bhuiyan, M.H.R., Shams-Ud-Din, M., Islam, M.N., 2012. Development of functional beverage based on taste preference. Journal of Environmental Science and Natural Resources 5(1), 83-87.

Bogdanov, S., Jurendic, T., Sieber, R., Gallmann, P., 2008. Honey for nutrition and health: A review. The Journal of the American College of Nutrition 27, 67-689.

Brand-Williams, W., Cuvelier, M., Berset, C., 1995. Use of a free radical method to evaluate antioxidant activity. Lebensm-Wiss u-Technology 28, 25-30.

Bray, H.G., Thorpe, W.V., 1954. Standard methods of biochemical analysis, Kalyani Publishers, New Delhi.

Bulut, L., Kilic, M., 2009. Kinetics of hydroxymethyfurfural accumulation and colour change in honey during storage in relation to moisture content. Journal of Food Processing and Preservation 33, 22-32.

Chen, L., Mehta, A., Berenbaum, M., Zangerl, A.R., Engeseth, N.J., 2000. Honeys from different floral sources as inhibitors of enzymatic browning in fruit and vegetable homogenates. Journal of Agricultural and Food Chemistry 48, 4997-5000.

FAO.,1996. Food and Agriculture Organization. Value-added products form beekeeping. FAO Agricultural Services Bulletin. Rome, Italy.

Fruit Products Order (FPO, 1955)., 2006. International Law Book Company, Delhi 25.

Gheldof, N., Engeseth, N.J., 2002. Antioxidant capacity of honeys from various floral sources based on the determination of oxygen radical absorbance capacity and inhibition of in vitro lipoprotein oxidation in human serum samples. Journal of Agricultural and Food Chemistry 50, 3050-3055.

Gopalan, C., Ramasastri, B.V., Balasubramanian, S.C., 2002. Nutritive value of Indian Foods. National Institute of Nutrition (ICMR), Hyderabad, India.

Government of India, 2005. Manual of methods of analysis of foods. Lab Manual 4, New Delhi 73.

Kaushik, R., Joshi, V.K., Gupta, J.K., 1993. Total soluble solids, acidity, $\mathrm{pH}$ and standard plate count in the Indian honey as affected by different treatments and storage conditions. Journal of Food Science and Technology 30 (6), 442-443.

Lakhanpal, P., 2010. Development and evaluation of honey enriched fruit nectars. M.Sc. Thesis. Dr. Y.S. Parmar University of Horticulture and Forestry, Nauni, Solan, Himachal Pradesh, India.

Lane, J.H., Eynon, L., 1923. Volumetric determination of reducing sugars by means of Fehling's solution, with methylene blue as internal indicator, IS1 XXV 143-149.

McKibben, J., Engeseth, N.J., 2002. Honey as a protective agent against lipid oxidation in ground turkey. Journal 
of Agricultural and Food Chemistry 50, 592-595.

McLellan, M.R., Kime, R.W., Lee, C.Y., Long, T.M., 1995. Effect of honey as an anti-browning agent in light raisin processing. Journal of Food Processing and Preservation $19,1-8$.

Mishra, R.C., 1995. Honeybees and their management in India. ICAR, New Delhi 168.

Mundo, M.A., Padilla-Zakour, O.I., Worobo, R.W., 2004. Growth inhibition of foodborne pathogens and food spoilage organisms by select raw honeys. International Journal of Food Microbiology 97, 1-8.

Nagai, T., Inoue, R., Kanamori, N., Suzuki, N., Nagashima, T., 2006. Characterization of honey from different floral sources. Its functional properties and effects of honey species on storage of meat. Food Chem 97, 256-262.

National Honey Board. 2003. www.honey.com.

Nchez-moreno, C.L., Plaza, Adeancos, B., Pilarcano, M., 2003. Vitamin C, provitaminA, carotenoids and other carotenoids in high-pressurized orange juice during refrigerated storage. Journal of Agricultural and Food Chemistry, 647-653.

Oszmianski, J., Lee, C.Y., 1990. Inhibition of polyphenoloxidase activity and browning by honey. Journal of Agricultural and Food Chemistry 381, 892-5.

Ouchemoukh, S., Louaileche, H., Schweitzer, P., 2007. Physicochemical characteristics and pollen spectrum of some Algerian honeys. Food Control.18, 52-58.
Poncini, L., Wimmmer, F.L., 1987. The composition of some fiji honeys. Apiculture Abstract 32(2), 281.

Ranganna, S., 2007. Handbook of analysis and quality control for fruit and vegetable products, McGraw Hill, New Delhi 976-979.

Saxena, S., Gautam, S., Sharma, A., 2010. Physical, biochemical and antioxidant properties of some Indian honeys. Food Chem 118, 391-397.

Singh, B., 1994. Studies on the physico-chemical characteristics of honey from important floral sources in Punjab. M.Sc. Thesis.PAU, Ludhiana.

Singh, N., Singh, S., Bawa, A.S., Sekhan, K.S., 1988. Honey: its food uses. Indian Food Packer 42(6), 15-25.

Subramanian, R., Hebbar, H.U., Rastogi, N.K., 2007. Processing of honey: A review. International Journal of Food Properties 10, 127-143.

Taormina, P.J., Nemira, B.A., Beuchat, L.R., 2001.Inhibitory activity of honey against food borne pathogens as influenced by the presences of hydrogen peroxide and level of anti oxidant power. Int Food Microbial 69, 217-225.

White, J.W., 1975. Composition of honey. In: Crane E, (eds). Honey, a comprehensive survey. London: Bee research Association and Chalfont, St Peter, 157-206.

www.honey.com-The National Honey Board | Home. Web. 03 Feb. 2010. <www.honey.com>. 